\title{
POETAS ÁRABES DEL PAÍS VALENCIANO
}

\author{
Margarita LACHICA \\ Universidad de Alicante
}

Calificamos de arábigo-valencianos, tanto a aquéllos poetas islámicos nacidos en los territorios que hoy forman parte del País Valenciano, como a aquéllos que se ligaron a él con su obra y con su vida, nos sea o no conocido el lugar de origen. Los que vamos a mencionar aquí son los siguientes: Ibn Darrāŷ al-Qastālī, Ibn al-Labbana de Denia, Ibn al-Yamanī, Abū-I-Walid Hissam Ibn Ahmad Al-Kinanī al-Waquaši, Abū Salt, Ibn García, Abū Abd-Allah ibn Aixa, Ibn Halsa, Ibn Jafaŷa de Alcira, Ibn al-Binnī o Ibn al-Battī, Ibn Tahir, Ibn Labbūn de Murviedro, Ibn Ruhaim, Ibn al-Zaqqaq, Ibn Mujdar, Al-Rusafī, Abū Yafar al-Waqqaci, Abū yafar Ibn Atiq, Abū-La-Qasim Abd-al-Rahman ibn Jarsus, Abū-l-Hasan 'Alī Ibn Sad Al Jair, Abū 'Alī alHusayn al-Naxxar, Ibn al-Arabì de Murcia, Ibn Marj al-Kuhl, Abū-I.Munsafi, 'Ali Ibn Hariq, Ibn Talha, Ibn Amira y, por último, Ibn al-Abbar.

La Bibliografía actual nos da muy pocos datos biográficos de estos poetas.

Tantos siglos de historia olvidada apenas si nos permiten, hoy, conocer algunas referencias mínimas, que nos hablen de la vida suya, de dónde nacieron y murieron, de cuáles fueron sus oficios o estudios y poca cosa más. De algunos, ni siquiera nos han llegado datos elementales y solamente sabemos de ellos el lugar de origen, el nombre de familia y algún que otro fragmento de la obra poética, o si ocupó algún cargo importante en la sociedad. Quizá por ésto el deseo de recordarlos ahora, intenta ser un desagravio a tanto recuerdo borrado. Al fin y al cabo, ellos vivían y amaban el mismo territorio que nosotros habitamos y estimamos hoy. No hay noticia de ningún poeta árabe de origen valenciano antes de la aparición de Ibn al-Labbana de Denia (s.XI). 
Veintitantos poetas en poco de más de dos siglos, es un número, bastante representativo, de cuál fue la contribución de los árabes valencianos al conjunto de la poesía árabe de Occidente.

Según diccionarios biobibliográficos de Al-Andalus se pueden contar, entre el siglo XII y primer tercio del XIII, cerca de 201 sabios de Valencia; 105 letrados en Játiva; 60 en Denia; 18 en Onda; 21 en Llíria; 33 en Alcira $y$ otros muchos en pequeñas poblaciones como Sogorb, Bairén, Concentaina ...

\section{IBN DARRAY AL-QASTALLI}

Abū Umar Ibn Muhammad Ibn Sulaymān Ibn Darrāŷ al-Qastālĭ.

Este poeta pasó en Valencia y Játiva 22 años cerca de los reyezuelos taifas Mubārak y Muddafar en Valencia y Játiva; la $3^{a}$ fase de su vida la vivió en Denia, en la corte del rey Muŷahid y en esta ciudad permaneció hasta su muerte ocurrida el 21 de junio de 1030 a los 72 años. Su nacimiento fue en Cazalilla (Jaén).

Muŷahid tenía a Denia como capital de sus estados. Era muy versado y supo atraer a la gente ilustrada honrándola con distinciones, al mismo tiempo que la recompensaba.

El profesor egipcio Mahmud 'Alī Makk̄̄ hizo un estudio sobre Ibn Darrāŷ en el Boletín de la Real Academia de Bellas Letras de Barcelona en 1963 y dice, que no se sabe cuántos años vivió lbn Darrāŷ en Denia.

Muchos autores árabes a partir de 1038 hacen grandes elogios del poeta. Ibn Jaldún (1406) lo nombra como uno de los más gloriosos poetas de la literatura árabe en España.

Su obra literaria está recogida en un Diwān que consta de 632 páginas, de las que 534 la ocupan 163 poemas y algunos fragmentos en prosa. Lo publicó 'Alī Makkī en Damasco en 1961.

Además de su valor, puramente literario $v$ estético es fuente documental sobre los acontecimientos en España.

Dedicó poemas a los reyezuelos taifas valencianos Mubārak, Muddafar $y$ al de Denia, Muŷahid. 
Alrededor del rey Al-Mutamid de Sevilla habia poetas como Ibn alLabbana. Abū Bakr Ibn 'Isa al-Danī, más conocido como lbn al-Labbana que significa "hijo de la lechera", nació en Benisa durante el reino de taifa de Denia, en fecha no muy clara del siglo XI, y es considerado como uno de los máximos representantes de la lírica árabe de Al-Andalus.

Ibn al-Labbana, lejos de su tierra natal, después de recorrer algunos de los reinos más cultos y afamados era un poeta reconocido de la corte sevillana, la más lujosa y refinada de al-Andalus. Pertenecía a la Academia que agrupaba a aquellos compositores que, oficialmente, superaban la admisión, en tiempo de al-Mutamid.

Junto con Ibn Zaydún de Córdoba; con Ibn 'Ammar de Silves y con el propio al-Mutamid configuran el siglo de oro de la poesía arábigo-andaluza, que es el siglo XI.

De Ibn al-Labbana lo que más se destaca, tanto de su vida como de su obra es la fidelidad y la gratitud con que respondió, cuando la hecatombe final destruyó a los 'abbadíes de Sevilla.

Yusuf, el almorávide, acabó con los reinos taifas, Sevilla fue tomada a los 'abbadíes el nueve o diez de septiembre y con ella su reyezuelo al Mutámid. En estos momentos de derrota los versos de lbn al-Labbana consiguen ser magistrales. Su lealtad queda reflejada en ellos cuando llora la derrota de los 'abbadíes y describe cómo embarcó al-Mutámid en el puerto de Triana hacia el destierro de Agmat.

Canta la agonía de un tiempo; de una Historia; de un momento cultural. Y no sólo escribe la ruina de Sevilla y de la corte 'abbadí; sino que llora la derrota de su mundo y de él mismo que, de ahora en adelante, no sabrá dónde parar y andará errante.

Hasta última hora lbn al-Labbana siguió a al-Mutámid que fue deportado hacia la prisión de Agmat, cerca de Meknés. No entró al servicio de ningún otro señor hasta que al-Mutámid murió.

De Ibn al-Labbana es conocida una muwassaha, composición de las consideradas populares, a pesar de ser uno de los mejores poetas cortesanos del siglo XI. El hecho no quiere decir nada peyorativo, ya que hasta el propio rey al-Mutámid llegó a cultivar este género; en todo caso significa que este estilo no era menospreciado por los mejores poetas cortesanos ya, en la época de los reyes de Taifas, aunque tenido por poco académico. Esta muwassaha de lbn al-Labbana que lleva el número 29 de 
la serie que García Gómez ofreció en su libro Las Jarchas romances de la serie árabe en sus marco, es un panegírico dedicado al reyezuelo de Toledo al-Mamún (1037-1075). Esto puede llevarnos a considerar la composición como una pieza de la juventud del poeta.

La muwassaha se inicia con un preludio, sigue dando una definición de la vida muy propia de la época y termina, después de los indispensables elogios al monarca toledano, con una estrofa en romance que canta una joven a orilla del mar.

Podemos decir que el mar, que tantas veces había servido de imagen poética a Ibn al-Labbana fue el que le ofreció la última compañía: acabó sus días en la isla de Mallorca.

Algunas noticias históricas nos dicen que pasó por Bujía y que poco después entró en la corte de Nasr al-Dawla, rey de Mallorca. Murió alli el año 1113. También los reinos de Taifas habian muerto y con ellos su esplendor y cultura. Ibn al-Labbana de Denia supo cantar la emoción de su agonía, tal vez, como ningún otro poeta.

Fue contemporáneo de lbn Ammar de Silves que fue uno de los mejores poetas del momento, en la corte de al-Mutámid del que era amigo íntimo. Se enteró lbn al-Labbana de que había hablado mal de él y le respondió con una sátira que decía:

Sus costumbres, oh pueblo, quieren competir con las mías

Opuestos somos en todo y nada nos une:

Yo soy "hijo de lechera" y él de un verdugo.

\section{IBN AL-YAMANI}

Abū 'Alī Ibn al-Yamanī al-Abbasī nació en lbiza y era conocido por el apodo al-Xabin̄ debido a que en esta isla existian muchas plantas, de nombre sabina, que es una variedad del enebro. La fecha de su nacimiento nos es desconocida, aunque han podido situarla en el siglo XI. Su familia se estableció en Denia.

Fue uno de los muchos poetas itinerantes, siguiendo la costumbre de su siglo, que recorrían las cortes taifas de Al-Andalus y se acercaban a la compañía de los poderosos para ofrecerles magníficos versos a cambio de dinero.

Ibn Sa'id cuenta, de este Ibn al Yamanī, que no componía una casida 
por menos de 100 dinares, elevada cotización que da una idea de la fama del poeta. Entre los protectores más espléndidos, que tuvo lbn al-Yamanī, destacó 'Alī Ibn Muŷahid al que dedicó numerosas composiciones, desaparecidas, hoy, casi todas. Hay versos suyos citados en las mejores antologias, que fueron escritos, según al-Maqqarī, en elogio de 'Alī lbn Muŷahid, el culto, pacífico y refinado príncipe de Denia.

No se sabe cómo, cuándo y dónde fue la muerte de Al-Yamanī.

\section{ABU-L-W'AIĪD HISSAM IBN AHMAD AL-KINANI AL-WAQASI}

Otro poeta y personaje significativo de este momento histórico es AbūI-Walid Hissan Ibn Ahmad al Kinanī, llamado al-Waquašī y tenido entre los sabios de la época.

Aunque nacido en un pueblo de Toledo (Waqaš, de donde le viene el nombre) en el año 1017, nos lo encontramos viviendo en Denia, durante los últimos años de su vida.

Considerado uno de los mejores gramáticos de Al-Andalus. Sus profundos conocimientos de las ciencias han hecho escribir a unos de sus biógrafos que "sobre cualquier cosa que se le preguntara él respondía".

Estuvo especialmente vinculado al Reino de Valencia, en donde ejerció su autoridad de sabio $y$ de político.

Entre sus composiciones poéticas más recordadas, figura una Elegía a Valencia, escrita durante el sitio a la ciudad por las tropas del Cid Campeador.

La muerte de al-Waqašī en Denia, ocurrió el año 1095, poco después de huir de Valencia y cuando Denia ya formaba parte del imperio almorávide. Era partidario de la no resistencia a los cristianos; ocupó el cargo de cadí, nombrado por el Cid.

Sanchís Guarner dice: "era tan grande el desconsuelo de los sarracenos en Valencia que, incluso al-Waqaši cesó en su cargo de cadí y se fue a Denia con los almorávides, donde en poco tiempo murió lleno de tristeza" por la gran represión, contra los árabes, por parte del Cid. 
Abū Salt Umayya Ibn 'Adb-al-Az̄̄z Ibn Abī Salt nacido en el año 1067 fue alumno del cadí al-Waqašī, de quien recibió formación. Heredó de él su cultura enciclopédica.

Si bien es cierto que su nombre se hizo célebre por su tarea científica, también fue estimado como poeta: 'Imad al-Isbahānī recogió su Diwān y en una obra suya (Harida) reproduce versos de Abū Salt. Todas las Antologías de la poesía de Al-Andalus se ocupan de él y recogen sus versos.

Los acontecimientos políticos y la muerte de su maestro hicieron, muy probablemente, que Abū Salt se alejara de la Xarquía y emigrara de AlAndalus. El abrió la huída a Oriente que otros continuaron, como Abū Bakr de Tortosa (1059-1125).

Después de 1096 lo encontramos por Alejandría y El Cairo donde continuó estudios y donde un hecho desafortunado lo llevó a la prisión por orden del rey.

Según algunas crónicas, también trabajó en la corte, de Sicilia, del normando Roger II.

Por último, desterrado de Egipto se dirigió hacia Mahdiya donde fue bien recibido por el emír y rodeado de gran consideración. allí permaneció hasta su muerte acaecida el año 1134.

Hizo versos en elogio de Yahya Ibn Tamīm, rey de al-Mahdiya, cuando éste iba a caballo.

La producción escrita de Abū Salt fue muy numerosa: como filósofo escribió un tratado de Lógica Aristotélica, que está considerado como la contribución valenciana más importante a la Filosofía Islámica.

También fue autor de un compendio de Astronomía; de un tratado sobre Medicamentos; un estudio sobre la Música y unas Epístolas Egipcias.

Entre sus composiciones poéticas destaca un epitafio. 


\section{IBN GARCIA}

Otros poetas, sabios y filósofos hubo en Denia durante el período del siglo XI, en que la gobernaron los Muŷahid.

De muchos, apenas si hay noticias confusas. De otros se conoce la cita del nombre.

Según $M^{a}$ Jesús Rubiera destacó Ibn García de Denia, cuyo nombre indica un origen hispánico. Escribió una Epístola defendiendo la superioridad de los no árabes, pero que eran musulmanes y arabófonos, frente a la etnia árabe.

Era un saqáliba, cautivo de niño y de origen vasco.

\section{$A B U \bar{U}$ ABD-ALLĀH IBN AIXA}

Sabemos que fué secretario de 'Alī lbn Yusuf lbn Taxufín.

En el Libro de las Banderas de los Campeones escrito por Ibn Sa'id alMagribī, hay un apartado que dedica a Valencia y refiriéndose a Ibn Aixa dice: "Cuenta Ibn Bassam en su obra al-Dajira que este poeta estaba, un día con Ibn Jafaŷa y un grupo de literatos, bajo un albaricoquero florecido $y$, como soplara un viento fuerte que hizo caer muchos pétalos, improvisó una poesía".

Ibn Aixa fue colaborador de los almorávides, como tantos otros de la Xarquía en este tiempo.

Era gran admirador del poeta Ibn Jafaŷa, cuyo estilo floral imitaba con elegancia.

\section{IBN HALSA}

Abū Abd-Allāh Muhammad Ibn Abd-al-Rahman Ibn Halsa aparece en el Kitāb al-Rawd al-Mi'tar del famoso recopilador al-Himyari. Este reproduce fragmentos poéticos de Ibn Halsa, personaje del que solamento conocemos su nombre. 
Abū Ishāq Ibrahīm Ibn Abū-I-Fath Ibn Jafaŷa. Nació el año 1058 en la ciudad de Alcira. Era hijo de un beréber de Hawwara, de familia acomodada y con tierras de cultivo. Vivió todo su tiempo en la tierra de sus orígenes donde consiguió la formación suficiente para ser considerado "la cima más alta de la lírica neoclásica. Era el mejor y más recordado de los poetas de Xarq al-Andalus. Lo llamaban el Jardinero por las metáforas florales de su poesía.

Ibn Jafaŷa escribió dos famosas elegías: una a la pérdida de Alcira y la otra es un lamento por la caída de Valencia en manos del Cid. Esta por sus imágenes épicas sabiamente combinadas; de un tono intimista y amargo, era tenida entre los más estimados lamentos de al-Andalus.

Hizo un Panegírico al General Mazdalī, el que asedió a Valencia en 1101 y venció a los castellanos en Cullera.

Lejos de la Corte recrea mundos estéticos exquisitos. Era el creador de una escuela poética de gran importancia. Vivió independientemente, sin buscar el apoyo, ni favor de los poderosos, ni dejarse tentar por sus ofertas: al contrario de lo que debian hacer los poetas para conseguir medios de vida.

Como la política es una de las funciones de la poesía árabe, cantó lbn Jafaŷa, al igual que los otros poetas de su tiempo, el advenimiento de la nueva dinastía y a su príncipe Ibn Taxfín (1145).

A pesar de ésto no es un poeta de Corte y prefiere vivir en su retiro provinciano, cantando la naturaleza exuberante de su región natal.

El profesor argelino Hamdán Haŷyayyi, que es el mejor investigador sobre la vida y obra de lbn Jafaŷa, lo considera como el Maestro de la Escuela Valenciana. No fue un simple imitador de los poetas orientales. Su poesía demuestra una originalidad extraordinaria y un estilo jafayí inconfundible. El mismo alude a los poetas orientales en el prólogo que escribe para su Diwán (Cancionero) y en la prosa que encabeza sus composiciones poéticas. Muchas veces les discute o corrige, como hizo con un verso de al-Mutanabbi (915-965) o con una qasida de Ibn Raxíq (995-1064).

Hay mucha diferencia entre él y el poeta sirio al-Sanawbarī, dado que éste describe los jardines durante el día, mientras el poeta de Alcira los describe al atardecer o durante la noche. La noche ocupa en su poesía un lugar y un tiempo destacado. Mahmúd Subh le llama el poeta de la noche 
por antonomasia.

En la poesía báquica no es menos que su contemporáneo persa, el gran poeta 'Umar-al-Jayyām y en la poesía homosexual no es inferior al poeta iraquía Abū Nuwás (756-814).

Sin embargo la fama, en estos dos temas poéticos tan desarrollados y frecuentes en la poesía árabe, la tienen estos dos poetas orientales.

Ibn Jafaŷa aparece en sus versos como un hombre sensual; amante de la vida y trata todos los temas en su poesía; pero cuando canta la Naturaleza, su poesía, se eleva más. Es en este aspecto en el que es más conocido: ríos, estanques, jardines, árboles, frutos y flores encuentran en él un cantor inspirado y apasionado. Es lo que le valió el sobrenombre de al-Yannán (el Jardinero).

Según García Gómez los paisajes de lbn Jafaŷa son deliciosos y pintados con arte insinuante, como escenarios de idilios o partidas báquicas. El mismo arabista dice que es -como Góngora en nuestras letrasla cima extrema de la lírica neoclásica que tras él, sólo puede repetirse o declinar.

Su influencia sobre los poetas fue enorme, empezando por su sobrino Ibn al-Zaqqaq (1134); al-Rusafī (1177) y otros.

El estilo jafaŷí llega a los últimos tiempos del Reino Granadino, en los versos de Ibn Zamrak, el poeta de la Alhambra, que plagia algunos de sus poemas.

Fue tal la fama de lbn Jafaŷa, en su misma vida, que su poesía se reunió en un Diwán y es uno de los raros diwanes completos que poseemos de poetas hispano-árabes. Se conserva en una docena de manuscritos.

Los antólogos andalusíes más importantes, le dedican lugar preferente en sus obras.

También figura en antologias orientales; y los libros escolares de todo el mundo árabe, contienen selecciones de sus versos. 
Abū Yaf'ar Ahmad Ibn 'Abd-al-Azíz Ibn al-Binnī o lbn al-Battī era tenido por experto genealogista. Murió quemado.

IBN TAHIR

Fue uno de los tantos poetas del momento de la recuperación de Valencia por los almorávides, después de la muerte del Cid. Sólo conocemos su nombre y los versos emotivos con los que describe la ciudad recobrada.

IBN LABBUN DE MURVIEDRO

Abū Issa Ibn Labbún. Sabemos que fue señor de Murviedro y uno de los magnates de su tiempo. Cadí de al-Mamún, rey de Toledo. Se declaró independiente cuando el tirano al-Qádir heredó el gobierno. No se atrevió a declararse príncipe soberano de sus dominios y pidió la protección de lbn Razín, señor de Albarracín, para poder defenderse del Cid. Ibn Razín lo desposeyó de su señorío y Murviedro. Poco después cayó en poder del Cid.

La muwaxaha de Ibn Labbún, que se conoce, tiene por tema el amor: el poeta enamorado de una esclava se humilla ante ella.

En el libro Poesía y Arte de los Arabes de España y Sicilia de Federico de Shack de otras composiciones cultas, al lado de esta composición popular.

Joseph Piera ha traducido al valenciano dos: una es un poema báquico $y$ otra es un fragmento de una elegía amorosa.

Se ignoran las fechas de su nacimiento y muerte, aunque su tiempo y su poesía pueden corresponder a los de la Escuela Valenciana de Ibn Jafaŷa.

IBN RUHAIM

Abū Bakr Muhammad Ibn Ahmad Ibn Ruhaim nació en Bocairente, localidad perteneciente al Reino de Denia. De él han llegado dos composiciones del estilo de la muwaxaha; una de carácter amoroso y otra 
un panegírico a un personaje de su tiempo. Sanchis Guarner transcribe y traduce la estrofa aljamiada de una de las composiciones de Ibn Ruhaim.

Se sabe que fue visir y almojarife de Sevilla, al servicio de los almorávides y que su nombramiento en estos cargos data de 1121, el mismo año que los almohades iniciaban su alzamiento, en Marruecos, contra el Imperio de los almorávides.

\section{IBN AL-ZAQQAQ}

Abū-I-Hasan 'Alī Ibn Atiyat Allāh Ibn Mutarrif Ibn Salma Ibn al-Zaqqaq. No sabemos el lugar ni el año de su nacimiento. Era hijo de una hermana de Ibn Jafaŷa de Alcira. La fecha de nacimiento puede ser calculada aproximadamente. Los historiadores dicen que el poeta murió joven, antes de los 40 años, sobre el 1133 ó 1135 . Esto les llevó a situar su venida al mundo en los finales del siglo XI, cuando Valencia era un señorío del Cid. No llegó a conocer la caída de los almorávides en 1146, con la invasión almohade. Su apodo Al-Balansī parece indicar que Valencia es la ciudad donde nació, pero no está confirmado. La Historiografía nos ha dejado poca cosa de la vida de Ibn al-Zaqqaq. Se sabe por su biógrafo, Ibn al-Aqbar, que sus versos "han sido compilados en Diwán" y que gozaron de mucha celebridad por los muchos fragmentos reproducidos en las Antologías. EI nombre del poeta ha sido confundido, a causa de su grafía árabe, con un tal Ibn al-Raqqaq y tenido por egipcio.

Anécdotas curiosas y confusas igual hacen de él un hijo de familia humilde, sin dinero para pagarse los estudios, como dicen que su padre fue al-muezin de la mezquita aljama de Valencia.

Sin duda la formación poética de Ibn al-Zaqqaq fue al lado de su tío lbn Jafaŷa, aunque éste no lo nombra nunca en sus escritos. Se sabe que cursó tradición profética con Abū Muhammad Ibn al-Sa'id al Batayawsī, maestro de gran fama entre la juventud valenciana de su tiempo.

El poeta e historiador Ibn al-Abbar dirá que "alabó a los grandes". Otros estudiosos, matizando esta expresión, aclararán que no fue uno de aquéllos ruedamundos a la manera del siglo $\mathrm{XI}$, ni tampoco ningún aventurero de aquellos panegiristas de oficio, vendedores de qasidas a buen precio. Como su tío Ibn Jafaŷa estuvo apegado a sus orígenes; $\sin$ estrecheces económicas.

La personalidad poética de Ibn al-Zaqqaq hoy es muy conocida y reconocida gracias a los estudios de Pérès y las traducciones castellanas 
de García Gómez.

Ibn al-Zaqqaq consideró a su época como hostil para los escritores. Llegó a decir de sus contemporáneos en su Epitafio a uno Mismo: "aunque parecen puros, detrás de ellos se esconde el odio como las brasas en el calor de las cenizas".

\section{IBN MUJDAR}

Abū Yahy ā lbn Abd-al-Yayil al-Fihrī Ibn Mujdar. Originario de Murcia, según los historiadores Ibn al-Abbar e Ibn Sa'id. Fue poeta de la corte de Ibn Mardanix, fastuosa en muchos aspectos, a pesar de que este rey es recordado, sobre todo por sus crueldades y afición a la guerra, más que por sus gustos poéticos. De los cantores de su corte las Antologías citan a Ibn Mujdar.

Desconocemos la fecha de su nacimiento, así como su obra, la cual se ha perdido. Nada más queda noticia de unos breves fragmentos conservados en antologías. Hay uno en el que se hace la descripción de un pino. Se sabe que murió en Marruecos el año 1192.

\section{AL-RUSAFI}

Abū 'Abd Allāh Muhammad Ibn Gālib al Rusafī: Es el mejor poeta de Valencia durante el período almohade, aunque vivió muy lejos de esta ciudad. Escribía su producción en Málaga. Es el gran cantor nostálgico de Valencia. Su Elegia Valenciana es la pieza maestra, no solo de este autor, sino de toda la poesía continuadora del estilo jafaŷí, escrita por los poetas arábigo-valencianos.

Nació en la Rusafa de Valencia, de donde le viene el nombre de alRusafī, en fecha que algunos historiadores sitúan a mediados del s.XII; tal vez en 1141, pocos años antes del primer desembarco almhohade en AlAndalus. Esta referencia resulta dudosa para muchos estudiosos. Se ignora, también, la edad en que el poeta abandona Valencia para instalarse en Málaga, con su familia, así como los motivos de este traslado.

Valencia y la Rusafa están en la memoria del poeta como la patria distante y estimada; el paraíso perdido de donde se fue joven y adonde volver es imposible. Esta distancia le inspira versos magníficos y convierte el hogar de sus antepasados en un nombre mágico, lleno de resonancias 
literarias que lo habían convertido en un paraíso ajardinado en los poemas de Ibn Jafaŷa o de Ibn al-Zaqqaq, poetas de los que al-Rusafī es considerado discípulo y continuador.

Aquello que en los maestros era palabra de posesión alegre, en alRusafí tiene un tono melancólico de cosa estimada $y$ perdida.

No hay muchos más datos de su vida. Los historiadores dicen que era asíduo de las tertulias literarias que se celebraban en Málaga y en Granada, en aquellos jardines frondosos, cantados en sus versos.

Las fuentes árabes refiriéndose a su personalidad nos lo describen como de carácter tímido, introvertido, ascético, con un planteamiento muy ético de la vida y muy poco aficionado al vino y las orgías, cosas que en cierta medida, parecen contradecir algunos aspectos de su poesía. En algunos de sus poemas aparecen como características personales la tendencia a la nostalgia, la tristeza o la angustia intimista. La abstemia y el ascetismo no encajan del todo en otro tipo de composiciones en las que el vino y las orgías son cantados con verso lúdico y apasionado.

Los poemas báquicos y eróticos tenían bastante tradición en la poesía hispano-árabe $y$, quizá, al-Rusafī trataba solamente de repetir, con elegancia una retórica establecida.

Se habla del homosexualismo de al-Rusafī; sin embargo recordemos que en la poesía neoclásica árabe son motivos tópicos o metáforas habituales la descripción de adolescentes, la referencia constante al copero, al amado, al esclavo negro que se baña, etc. Seguidor de los modelos inspirados e implantados por la Escuela Valenciana, no fue nunca vulgar imitador de lbn Jafaŷa y de Ibn al-Zaqqaq, sino el heredero legítimo de este estilo que él supo renovar. Aunque utilizó recursos semejantes los llevó más allá, en sus posibilidades expresivas, de donde los habían dejado los dos grandes maestros de la Escuela Valenciana. Escribió bajo los dictados de su alma y no siguió la voluntad de los poderosos dispuestos a pagar con oro un panegírico. El se enorgullecía de su independencia.

En cambio los grandes señores, movidos por la fama y el prestigio del poeta, iban a pedirle sus bellos versos, buscando la inmortalidad, que solamente él podía darles. Murió en Málaga, según unos cronistas en 1177, cuando tendría treinta y tantos años, pero otros creen que murió más viejo.

Con la muerte de al-Rusafí la poesía hispano-árabe perdió el último de los grandes autores del siglo XII. Se le ha llamado el lbn al-Rumi de alAndalus, comparándolo con el de Bagdad. 


\section{ABŪ YA'FAR AL-WAQQAXI}

Fue visir de Ibn Hamusk, el suegro de Ibn Mardaniš, reyezuelo de Valencia. Por discordias entre éstos, Ibn Mardaniš arrasó todos los dominios de lbn Hamusk y de aquellas personas que habían quedado fieles a éste. Por eso destruyó un molino de al-Waqqaxī. El poeta respondió con unos versos amenazadores que Ibn al-Abbar reprodujo. Se recuerda a alWaqqaxī no tanto por los versos circunstanciales que escribió, como por los elogios que al-Rusafī le dedicó.

ABŪ Y'A'FAR IBN ATIQ (1159-1204)

Sabemos que fue conocido filósofo; y poeta muy entendido en tradiciones; cortesano del Califa almohade Abd-al-Mumin.

\section{ABŪ-L-QASIM ABD-AL-RAHMAN IBN JARŠUŠ}

El libro de Las Banderas de los Campeones de Ibn Sa'id al Magribī nos lo presenta como de Alcira y del s.XII, sin más datos ni fechas. Al-Imad incluyó en su obra Jarida versos de lbn Jaršuš.

\section{ABŪ -L-HASAM 'AII IBN SA`D AL-JAIR}

Sólo tenemos noticia de un poema suyo sobre La Senia.

ABŪ 'AII AL-HUSAYN AL-NAXXAR

También se le conoce por un poema.

IBN AL-ARABI DE MURCIA (1165-1240)

Autor de obras místicas, tanto en verso como en prosa. 


\section{SEGUNDO PERIODO ALMOHADE}

IBN MARJ AL-KUHL

Abū Abd-Allāh Muhammad Ibn Idris Ibn Marj al-Kuhl, nació en Alcira el año 1159. A pesar de ser muy alabado por sus biógrafos, apenas si nos dan datos de su vida. Unos dicen que de vendedor de pescado en los mercados pasó a ser cantor de príncipes; otros señalan que vestía descuidadamente y que era analfabeto. Parece evidente que venía de familia humilde y que, en su tiempo, fue considerado un talento poético. En la actualidad se le tiene por un poeta menor entre los seguidores de la Escuela Valenciana. Por al-Ruaimi, que recibió de él la licencia de su obra poética, se sabe que vivió algún tiempo en Córdoba y en Murcia; por Ibn al-Jatíb que pasó por Granada; y por otras fuentes, se sabe, que residió en Sevilla.

Escribió unos versos, no se sabe por qué motivo, que con una lectura actualizada, pueden sugerir una especie de autorretrato.

Siguiendo las directrices orientalizantes, Marj al-Kuhl fue poeta muy conocido y admirado por sus contemporáneos. Lo denominaron el Ibn Sa'id al Wawa de al-Andalus. Se sabe que murió en Alcira el año 1236.

\section{ABÜ-L-MUNSAFI}

Abū:I-Hajjaj Yusuf Ibn Ahmad al-Ansarī al-Munsafī al-Balansī. Nació en Almusafes en fecha desconocida. Se sabe que vivió a lo largo del siglo XIII y que después de expatriarse murió en Ceuta.

Al-Makkarī habla de él en tres ocasiones: en la primera lo llama Abū Abd-Allāh de Munsaf (Valencia), y añade que murió en Ceuta. En la segunda lo cita solamente considerándolo proveniente de al-Andalus. En la $3^{\text {a }}$ lo identifica como Abū Hajjaj Yusuf Ibn Ahmad al-Ansarī al-Munsaf de la región de Valencia.

Ibn Sa'id al Magribī dice en su obra Al-Mugrib que era de la alquería alMunsaf de la región de Valencia y que vivió en Ceuta.

Este mismo antólogo en el libro de las Banderas de los Campeones, sitúa al poeta valenciano, al que califica de ilustre y de santo, en el apartado correspondiente a Ceuta y entre los personajes que siguieron el camino de la piedad y del ascetismo diciendo "mi padre me recitó estos 
versos de al-MunsafĪ" que el mismo poeta le habia transmitido. $Y$ expone dos poemas.

\section{'AII IBN HARIO}

Abū-Hasan 'Al̄̄ Ibn Hariq al-Makhzumī. Nació en Valencia en 1156. Fue tenido por poeta de talento en su época. Hoy se le considera de menor importancia. Profundo conocedor de la cultura oriental, era un enterado en cuestiones literarias y de lengua. Lo demuestra el hecho de que fuera el maestro de Ibn al-Abbar, el historiador y poeta más significativo de este período, entre los valencianos. Epígono de la Escuela Valenciana. De Alí lbn Hariq y de su vida no se sabe más que murió en 1225.

Sus versos más conocidos son los dedicados a unas galeras $y$ los dedicados a Valencia.

\section{IBN TALHA}

Ibn Talha, poeta arábigo-valenciano nació en Alcira. Fue secretario de los almohades. Pasó más tarde al servicio del rebelde lbn Hud, al que dedicó sus versos florales y algunos panegíricos retóricos, hasta que se enemistó con Ibn Hud al-Mutawakkil y tuvo que huir a Ceuta. Allí murió asesinado en 1234.

\section{IBN AMIRA}

Abū-I-Mutarrif Ibn Amira nació el 1184 o el 1186 y no se puede afirmar si en Valencia o en Alcira. Unos creen que nació en Valencia pero otros creen que fue en Alcira. Fue cadí de Mallorca.

De entre sus obras destaca la relación de la conquista de Mallorca por Jaime I. Fue tenido por gran historiador y jurista.

Escribió epístolas para su amigo lbn al-Abbar que han merecido atención especial de los estudiosos. De éstas algunas fueron compiladas por al-Himyarī durante el s. XIV. Han liegado hasta nosotros traducidas al francés por Leví-Provençal; al castellano por Mata López y por Manuel Sánchez al catalán.

Desterrado a Túnez, Ibn Amira moría allí siendo secretario del califa 
hafsí al-Mustánsir. La fecha de su merte también es confusa; igual es situada por los años 1251 ó 1258 que alrededor de 1268 ó 1270.

\section{IBN AL-ABBAR}

Abū 'Abd Allāh Muhammad Ibn 'Abd-Allah Ibn al-Abbar al-Qudaí nació en Valencia en 1199. Su personalidad no sólo es apreciada como poeta sino que, aún es mucho más valorada y célebre como historiador, tradicionista y antólogo.

Estudió en Valencia con los muchos maestros que había allí y cuyas vidas y obras consignó en un repertorio biográfico titulado $\mathrm{Mu}^{\prime} j a n$. Maestros suyos, entre otros, fueron Abū-l Rabi Ibn Sālim y 'Alí Ibn Hariq.

También escribió una continuación del Repertorio de Ibn Baxkuwal titulado Takmila.

Como poeta su composición más famosa es la qasida en sin, que recitó al sultán de Túnez. También se han conservado fragmentos aparecidos en antologías como una qasida dedicada al sultán hafsí Abū Zakariya.

Tomada Valencia por Jaime I, Ibn al-Abbar emigró a Túnez. Allí escribió sus obras más importantes sobre la literatura de su patria: Tuhfat al-Qádim, antología poética con la que continuó la de Safwan Ibn Idris y al-Hulla alSujara (La túnica recamada), repertorio biográfico y antología de los poetas de al-Andalus, muy citada por los historiadores. Durante su destierro, en Túnez, fue secretario de los sultanes, hasta que cayó en desgracia y lo encarcelaron. Entonces escribió un libro titulado Faltas de los Secretarios, con las biografías de aquéllos que, también caídos en desgracia, después fueron perdonados. Este libro le valió la rehabilitación; pero más tarde volvió a la prisión y esta vez no le sirvió de nada su cultura y erudición, ni tampoco su poesía. Fue ejecutado el año 1260 . Mucha de la obra de lbn al-Abbar se ha perdido. Lo que ha quedado demuestra suficientemente que fue el último gran exponente y continuador de la cultura literaria de AlAndalus. Huici Miranda considera Ibn al-Abbar como uno de aquéllos ingenios que aparecen en los días peores de una civilización, para salvar su honra y dejar su nombre rodeado de prestigio. 


\section{BIBLIOGRAFÍA}

Alemán Saiz, Francisco:

al-Mazūrqī:

Asín Palacios, Miguel:

Barceló Torres, $\mathrm{M}^{\mathrm{a} C}$ Carmen:

Cabanelas, Dario:

Carmona Gonzalez:

Continente Ferrer, J.Manuel

Dirani, Mahmūd

Djerrane

Durá Rodríguez, Antonio

Epalza Ferrer, Mikel de

Fuster, Joan

García Albaladejo, Fco.
"Dos árabes murcianos Homain Ben Isaac y Abmarobí". Boletín de información municipal de Murcia num. 82. Ayuntamiento de Murcia, 1973.

Actas del IV Congreso Hispano - Tunecino. Madrid Instituto Hispano Árabe de Cultura, 1983.

Ibn Arabi de Murcia. Risalat al-Qubs. Escuela de Estudios Árabes de Madrid y Granada. 1939.

"Otros poetas también Valencianos". Anúbar (Temas Valencianos, 4). 1977.

Ibn Sida de Murcia.

"Algunas notas apresuradas sobre la poesía de Murcia en lengua árabe".Azahara II, 1980

Lisān al -Din Libro de la magia y de la poesía. Edic. y traducción española. Madrid, Instituto Hipano Árabe de Cultura, 1981. Temas y autores del Levante de alAndalus.

Diwān Ibn al-Zaŷyaŷy al Balansi. Beirut, 1965. Colección de poemas de este escritosr valenciano de los siglos XI-XII.

"La Poesía de la naturaleza de Ibn Jafacha". Orán, 1976.

Seis poetas árabes de Murcia. Azahara, Murcia, 9; 1980.

"Ibn Sĩda y Denia". Revista del I.D.E.A., Alicante, 2, 1981.

Poetes, moriscos y capellans. Valencia, L'Estel, 1962.

"Hāzin el de Cartagena poeta del Istām". Azahara, Murcia, 9, 1980. 
García Gómez, Emilio

Guichard, Pierre

Haŷaŷi, Hamādi

Harrar, Abd al-Salam

Huici, Ambrosio

Jiménez de Buen, E.

Lachica Garrido, Margarita

Lator, Esteban

Makki, Al-Ṭahir 'Ahmad

Menéndez Pidal, $M$.
"Árabe en endecasílabos: Poesía de Ben alZaqqaq". Revista de Occidente, 1976. Poemas traducidos de Ibn al-Labbana de Denia e Ibn al Zaqqaq de Valencia (s. XIXII).

Nuestra Historia. Mas Ivars, Valencia, 1980 Vol. III.

"Ibn Jafacha".S.N.E.D., Argel, 1974. Poeta del Alzira del s. XI-XII

"Vie et oeuvre du poête aldalou Ibn Jafaya". S.N.E.D., Argel, 1969.

"El Diwān de Ibn al-Abbar". Revista de la Universidad de Madrid,XV, Madrid, 1966.

"Ibn al-Labbana". Cuadernos de la Biblioteca española de Tetuan. Tetuar, 1967.

Historia musulmana de Valencia y su región. Valencia.

"Tres poemas hispano-Arábigos". Mauritania $X X X I$, Tánger, 1958. Traducción de un poema de Ibn al-Labbana de Denia s.XI.

"Tres fecundos poetas de Blad al-Andalus". Mauritania XXXI, Tánger, 1958. Traducción de un poema de Sa'ad al Jayr de Valencia s.XII.

"El poeta Ibn Darr āŷ al-Qastallī en Denia". Actas del Primer Congreso de Historia del País Valenciano, Vol II, Valencia, 1980.

"lbn Sab'īn de Murcia y su Budd al-Ārif". Al-Andalus, IX. Madrid-Granada, 1944.

"Dirasāt Andalusiyya". Dar al-Maārif El Cairo, 1980. Estudio sobre al-Andalus con los poetas del s.XI y XII que cantaron la pérdida de Valencia.

"Sobre alwacaxi y la elegía árabe de 
Molina López, Emilio

Munis, Husayn

Nilk

Péres, Henri

Piera, Joseph

Ribera y Tarragó

Riquelme Salar, José

Rubiera Mata, Ma Jesús
Valencia". Homenaje a D. Fco. Codera en su jubilación del profesorado. Zaragoza, 1904.

"Azīz ibn Jattāb, destacada personalidad literaría murciana del siglo XIII". Miscelánea Medieval murciana. Murcia, 1978.

"La Wizāra 'Isamiyya de Orihuela, el más prestigioso centro cultural de al-Andalus en el siglo XIII". Anales del Colegio Universitario de Almeria, Letras. Almeria, 1979.

"Consideraciones sobre la época de los reyes de Taifas". Al-Andalus XXXII, Madrid, 1966.

"La elegía árabe de Valencia". Hispanie Review. Philadelphia, 1940.

La poesie Andalouse en arabe classique au $X I$ siècle. Esplendor de al-Andalus trad. de Mercedes García-Arenal. Libros Hiperios, 61, Madrid, 1953.

Poemesdel'oriented'al-Andalus. Barcelona. Edicions, 62.

Els poetes arábigo-valencians. Valencia. Institució Alfons el Magnànim, 1986.

"La elegia de VAlencia y su autor". El Archivo Denia, 1887

"Moros celebres valencianos en literatura y viajes". El Archivo /, Denia, 1886-87.

"El murciano Ben Arabí y la Divina Comedia." Murgetana num.25, Murcia, 1965.

"Las décimas del Profeta". Al-Qāntara num. Madrid, 1965. Poemas de murcianos $y$ valencianos.

"La corte literaria de ibn Sa'îd de Menorca". 
Revista de Menorca LXXV, Mahon, 1984. "Un benissero ilustre: el poeta Ibn alLabbana". Tercer centenari Purissima Xiqueta, Benissa, 1984.

Terés Sádaba, Elias

Turky, Abd al-Magid

Vernet, Juan
"Textos poéticos arabes sobre Valencia". Al-Andalus XXX, Madrid, 1965. "Polemique entre Ibn Hzam et Bāg ī". S.N.E.D., Argel, 1975.

Literatura árabe. Nueva Colección Labor. Barcelona. 